\title{
人体の非侵襲的脂質等代謝測定法の開発と評価
}

\section{Development of Non-invasive Measurement System of Lipid Metabolism in Human and Its Assessment}

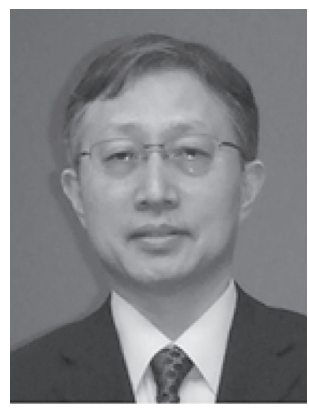

\author{
吉田 敏 \\ 岐阜大学大学院工学研究科 生命工学専攻 \\ T 501-1193 \\ 岐阜市柳戸 $1-1$ \\ Satoshi YOSHIDA \\ Faculty of Engineering, Gifu University \\ 1-1 Yanagido, Gifu 501-1193, Japan
}

論文要旨：人体の脂質・脂肪酸の動態を調べるときは, 通常は血液を医療機関で採取してその血清や血球 中の脂質・脂肪酸を生化学的検査あるいはクロマトグラフィー法等を用いて臨床検査室において測定し, 様々 な病態との関連を調べることになる。これに対して，この人体の脂質脂肪酸動態をどこでも手軽に，かつ非 侵襲的即時的に計測して個人の健康管理に役立つような技術を開発しょう，という試みはかなり前から行わ れてきた。特に，フーリエ変換赤外分光法（FTIR）などの振動分光法を用いた脂質脂肪酸測定方法の開発 は有望であり，近年の測定装置の小型化と解析技術の進歩と相俟って，実用段階に入った感がある。また， リポタンパク質動態を疫学的に調べるために血清の核磁気共鳴（NMR）分光法を用いた非破壊的検査法も 実用化されて久しく，盛んに疫学的研究に貢献している。このような多数の試料に対して，短時間での計測 に向いた分光法を使った脂質脂肪酸の評価法の，今後の発展が期待される。

\begin{abstract}
Lipid and fatty acid metabolism in human is usually measured by using whole bloods or sera of subjects and by detecting lipids and fatty acids in serum or erythrocytes with biochemical and chromatographic apparatus in clinical laboratory. On the other hand, many trials have been made for a long time to develop non-invasive diagnostic methods for monitoring lipid and fatty acid metabolism in human instantly at anywhere and anytime, especially to contribute for personal health care. For this purpose vibrational spectroscopy such as FTIR used for lipid and fatty acid measurements seems promising because of its analytical advancement and mobility. The technique of NMR spectroscopy for non-destructive measurement of human serum lipoproteins has been established and contributed to various epidemiological researches. These spectroscopic techniques are suitable for non-invasive or non-destructive and instantaneous measurements, and expected for further development of clinical measurements of lipid and fatty acid metabolism in human.
\end{abstract}

Key words: lipids, fatty acids, metabolism, non-invasive, spectroscopy, human

\section{1 はじめに}

生体, 特にヒトの脂質・脂肪酸の動態を調べるという 場合は，通常は被験者の状態のある瞬間を反映する被験 者の血液を用いて, 生化学的あるいはクロマトグラ フィー技術などによって臨床検査機関において脂質・脂 肪酸の変動が測定されている。

連絡者：吉田 敏

E-mail : xyosida@gifu-u.ac.jp
ヒトの脂質・脂肪酸代謝の状態を調べるには, 厳密に はヒトの組織細胞内の状態と, 細胞外である血液の状態 を分けて考える必要がある。臨床検査の場合は血液の脂 質・脂肪酸量の変動でもって「体の脂質脂肪酸代謝」の 状態を判断することが多いが, 本来体内脂質脂肪酸動態 は, 肝臓や筋肉などの組織細胞内の状態と, 細胞と血液 の間の輸送の状態と, 血液中の脂質脂肪酸量の変動（さ らに厳密には血漿と赤血球等の血液細胞内の状態に分け る必要がある）とに区別して観察していって，それらを 
統合して判断していくことで体の脂質代謝の全体像を把 握することができるはずである。ところが，このような 細胞内の代謝動態や輸送活性を通常の臨床的な検查で測 定することは，ほとんどされてはいない。

それに対して, 人体の脂質脂肪酸の血液以外の組織細 胞での代謝動態を，いつでもどこでも，かつ非侵襲的即 時的に計測して個人の健康管理に役立つような技術が確 立できれば，この分野では極めて大きな進歩となる。

これまでの非侵襲的非破壊的な脂質脂肪酸計測法の技 術開発の歴史の中で, 基本的に使われてきた計測法は電 磁波を用いた分光法（スペクトロスコピー法）である。 その中でも特に赤外分光（IR）法，近赤外 (NIR) 分光 法, レーザーラマン散乱分光法などのいわゆる振動分光 法と，核磁気共鳴（NMR）分光法である。これらの技 術の中で，フーリ工変換赤外分光（FTIR）法は NMR 法とならんで化学分析に扔ける基礎的技術の一つであ り，精度が高く装置も小型のものもあり手軽に使える方 法であるため, 最近では生化学分野でタンパク質定量法 としてルーチンに使われるような装置が開発されたり (Millipore 社)，また培養細胞のバイオプロセスのリア ルタイムモニターに使われたり (Mettler 社), と応用 範囲が広がってきている。

この総説では，これらの技術がヒトの脂質脂肪酸代謝 の評価にどのように貢献してきたか，また今後臨床診断 にどのように期待されているのか, 我々の研究を含めて 振り返り, 今後の課題について論じたい。

\section{2 非侵襲的非破壊的脂質脂肪酸代謝計測法の技術的背景}

これまでの脂質あるいは脂肪酸の測定の標準的方法 は，高速液体クロマトグラフ法 (HPLC)，ガスクロマ トグラフ法（GC）などクロマトグラフィーを基本にし て様々な高感度検出器 (蛍光検出器や質量分析装置など) を装備して測定するものである。これは，理想的には一 つの成分だけに物理的に分離してから測定するものであ り，充分信頼できる方法としてルーチンに使われてきて いる。ただし，この分離的方法は，試料の前処理に時間 を掛け多くの有機溶媒やガスを必要とし，分離するため に時間をかける必要があり，結局信頼のおけるデー夕を 得るには手間と時間（とお金）のかかる方法であった。 このような分離的手法は，時間的（場合によっては空間 的）に成分物質をお互いに分離する，いわば時間スケー ルの上に物質を 2 次元的に並べる作業である。

これに対して，スペクトロスコピー的手法の一つは, 基本的には各成分物質の持つ固有のエネルギー分布（又 ペクトル）に従ってそれらの混合物をデコンボリュー ション（逆たたみ込み）する手法であり，いわばエネル
ギースケールの上に各成分を 2 次元的に並べる手法とよ んでもよい。即ち，たたみ込まれた各成分のスペクトル を統計的（数学的）方法で抽出し解析する手法である。

もう一つのスペクトロスコピー的手法では, 混合物の 各成分の固有のスペクトルが明膫には分かっていなくて も, 多数の成分の混合物の中で, ある一つの成分の量が 明確に分かっていて，その成分量が異なる何種類かの混 合物のスペクトルがある場合，それらのスペクトルから 多変量解析的な処理によってその成分量に関するパラ メー夕を求めて, 未知の混合物のスペクトルからその成 分量を推定する回帰分析的手法がある。この手法ではあ る成分の量が異なる混合物試料 7 10 のサンプルを用い てキャリブレーションを行い，パラメータを求める。こ の場合，実際にはいくつかの最適な波数領域を設定し PRESS 值という予測誤差が最小になるように因子の数 を設定する，など細かな設定作業が必要になり専用のソ フトウェア (Panorama ${ }^{\mathrm{TM}}$ など) を用いて行う。一旦最 適なパラメータが決定されれば，それによってその成分 量が未知の混合物のスペクトルから, 瞬時にその成分量 をコンピュータ处理だけで推定することができる。ここ で使われる方法として主成分分析法に近い部分最小二乗 回帰分析（PLS ; Partial Least Squares Regression）等 が知られていて，以後略してPLS 法と呼ぶが，もっと 広義ではケモメトリックス (Chemometrics) 的手法 ${ }^{1}$ と呼ばれることも多い。

\section{3 赤外分光法による脂質脂肪酸代謝計測法の開発}

実際の赤外分光法では, 近赤外分光法やレーザーラマ ン散乱法などの振動分光法まで入れると, 脂肪酸組成分 析法だけでも多くの報告がある ${ }^{2-6)}$ ここの小論では私達 の研究を中心にFTIRによる種々の生体組織中の脂質脂 肪酸分析に絞った成果をご紹介したい。

\section{3・1 FTIR による脂肪酸組成の予測（食用油脂，ヒト 口腔粘膜)}

全反射（ATR）方式の FTIR 装置（FTIR-ATR）を 用いて, 試料との接触面 $(2 \mathrm{~mm}$ 径のダイヤモンドプロー ブ）で試料の深さ方向で約 $1 \mu \mathrm{m}$ の試料の IR スペクト ルを測定する場合，試料は液体でも固体でもよい。試料 がダイヤモンドの面ときちんと密着している必要があ り, これが感度を左右する。液状の食用油脂の場合は, 何の前処理も無しにそのまま小さな 1 滴の油脂を ATR プローブに載せるだけで測定できる。これで様々な油脂 を測定し企業から提供されている脂肪酸組成表を元に (一部は研究室でも脂肪酸組成を測定), いくつかの脂肪 酸についてPLS 解析を抢こなった。その結果, 食用油 脂中のオレイン酸やリノール酸, $\alpha$ リノン酸などの組 
成を FTIR-ATR 法で実用的なレベルで予測できること がわかった ${ }^{3)}$ 。さらに最近, 食品の様々な栄養素の簡便 分析にも赤外分析法が使われることが期待されている7)。

一方, ヒトの体の状態や病態を知る上で血液や組織細 胞の脂肪酸組成を測定することは，臨床医学的にも栄養 学的にも重要である。しかし, 多数の検体について脂肪 酸組成を従来のガスクロマトグラフィーなどによって測 定するのは，時間的にも労力的にもコスト的にも大変で ある。そのため, 多数の検体の測定を必要とする疫学的 研究にFTIRによる脂肪酸分析が使えるかどうか, 検討 することにした。

ヒトの口腔粘膜細胞の懸濁液を用い（イラン， ベトナ ム，インドネシア各国から全 425 試料を集めて冷凍して おいたもの)，遠心して得た細胞ペレットをFTIR-ATR 法で直接赤外スペクトル測定を行ない，その中の 10 数 検体だけ GCMS 法により正確に脂肪酸組成を測定し た。それからそれ以外の試料にPLS 法を適用し，いく つかのメジャーな脂肪酸の組成を粘膜細胞の赤外スペク トルから予測することができた。しかし，DHAなどの 割合の少ない脂肪酸の組成予測は誤差が大きく，実用的 とはいえなかった。例えば口腔粘膜のリノール酸（C18： 2 n-6) の Content（\%）のヒストグラムを作ると，イラ ン国民の場合の最頻值（Mode）は $11 \%$ だが, ベトナム では $13.5 \%$ ，インドネシアでは 15\%であり，各国の食生 活の違いの影響と思われる結果を得ることができた ${ }^{6)}$ 。

\section{$3 \cdot 2$ 口唇を通して測定したドコサヘキサエン酸(DHA) と過酸化脂質の代謝}

ヒトの脂肪酸代謝の研究は過去にいくつか行われてい るが，すべて血液を用いた研究であり，安定同位体でラ ベルされた脂肪酸を通常の食事の中で摂取し，その脂肪 酸がどのような時間経過で血漿や赤血球膜に取り达まれ ていくかをチェイスしたものである ${ }^{8)}$ 。この方法では, 摂取した脂肪酸が血液以外の各組織細胞に取り达まれて いく時間経過は報告されていなかった。そこで，食事で 摂取した脂質脂肪酸が，消化管で吸収され血流に乗って 肝臓や皮膚などの組織に運ばれ組織の細胞に取り达まれ ていく，という代謝の様子を簡便に見る方法の構築をめ ざした。当然肝臓などの内臓組織への取り达みは生検と いう手術行為が必要なので簡便にはできないので, 皮膚 組織への取り込みがあれば外からでも比較的容易に観測 できるかもしれない，という考えで皮脂腺の無い口唇表 面を直接 FTIR 測定することを試みた（装置については 次のセクションで述べる)。

その結果我々は, FTIR-ATR 法によってヒト口唇を 測定するとその口唇表面に食事で摂取したDHA を含む トリグリセリド（TG）が $1 〜 2$ 時間後に出てくることを in situ で観測することができた ${ }^{9)}$ 。

以前我々は口腔粘膜（下唇の内側）にFTIR-ATR プ ローブ（棒状の $\mathrm{ZnSe}$ 結晶）を直接当てて血液中のトリ グリセリド值を予測する方法を提案したが ${ }^{9)}$, 口唇赤色 部を使うとより効果的に脂質代謝を観ることができるこ とがわかった。これは，FTIR でDHA に特徵的な 3013 $\sim 3014 \mathrm{~cm}^{-1}$ 付近の, シス型アルケン $\mathrm{CH}$ 伸縮振動由来 の赤外吸収スペクトルの時間変化を解析することで，明 らかにできた。不飽和脂肪酸の不飽和度が高くなるほど この $\mathrm{CH}$ 伸縮振動由来の赤外吸収位置が高波数側にシフ トすることがわかっていて，オレイン酸は $3005 \mathrm{~cm}^{-1} に$ 見られ、リノール酸は $3009 \mathrm{~cm}^{-1} に$ に,アラキドン酸は $3012 \mathrm{~cm}^{-1}$ に見られる。さらに, 過酸化不飽和脂肪酸が できる時に生じるトランス型不飽和脂肪酸が昼ごろ口唇 表面で増え，その後減少することもFTIR で観測でき (968 $\mathrm{cm}^{-1}$ 付近で測定)，実際口唇表面のヒドロペルオ キシド体の生成の生化学的検出によって FTIR 法での変 化を裏付けることができた（Fig. 1)。このDHA を含む 脂質 (TG) の消化管での吸収 $\rightarrow$ 血流 $\rightarrow$ 組織細胞取り达 み(ここでは口唇組織) という代謝の様相を「代謝スピー ド」と表現すると, 成人男性で契煙しているヒトと, し ていないヒトではその「代謝スピード」が違い喫煙者で

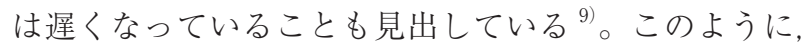
口唇表面には皮脂腺や汗腺がなくても脂質類が「出てく る」のを直接観測することができたが，この場合脂質類 は次のセクション $3 \cdot 3$ で述べる細胞間ラメラ (Intercellular lamellae）の状態で「滲み出して」くるのであろう と考えられる。皮膚表面は角質細胞 (Corneocyte) が 何層にも重なっていて, 生体にとってはバリアとしての 機能を持っているが，その角質細胞の間を細胞間ラメラ が動いていると考えられている。その細胞間ラメラは角 質層の下にある顆粒層や基底層などの細胞や毛細血管の 血液とも物質交換をしながら皮膚の性質の維持（保湿性 など）に貢献している。角質層の薄い口唇の場合, 滲み 出してくる脂質類の変化はFTIR で見たところ周期的に 起こるので (周期 20 分程度), 一方向の滲み出しではな く内向きの再取り込みの流れもあると考えているが，ま だ十分には証明されていない。

\section{$3 \cdot 3$ FTIR による口唇生体分子変化の測定と病態診断 (HbA1c 值予測)}

上記セクションでも述べたが，ヒトの口唇赤色部には 他の顔面皮膚と違って汗腺や皮脂腺がない。そのため口 唇表面の生体分子は各腺組織の独自代謝の影響を受け ず，口唇表皮組織（基底層，有棘層，顆粒層など）ある いは血液成分の影響を直接受けて, 表面角質層の細胞間 ラメラという脂質と水溶性物質の混合物の染み出しに 


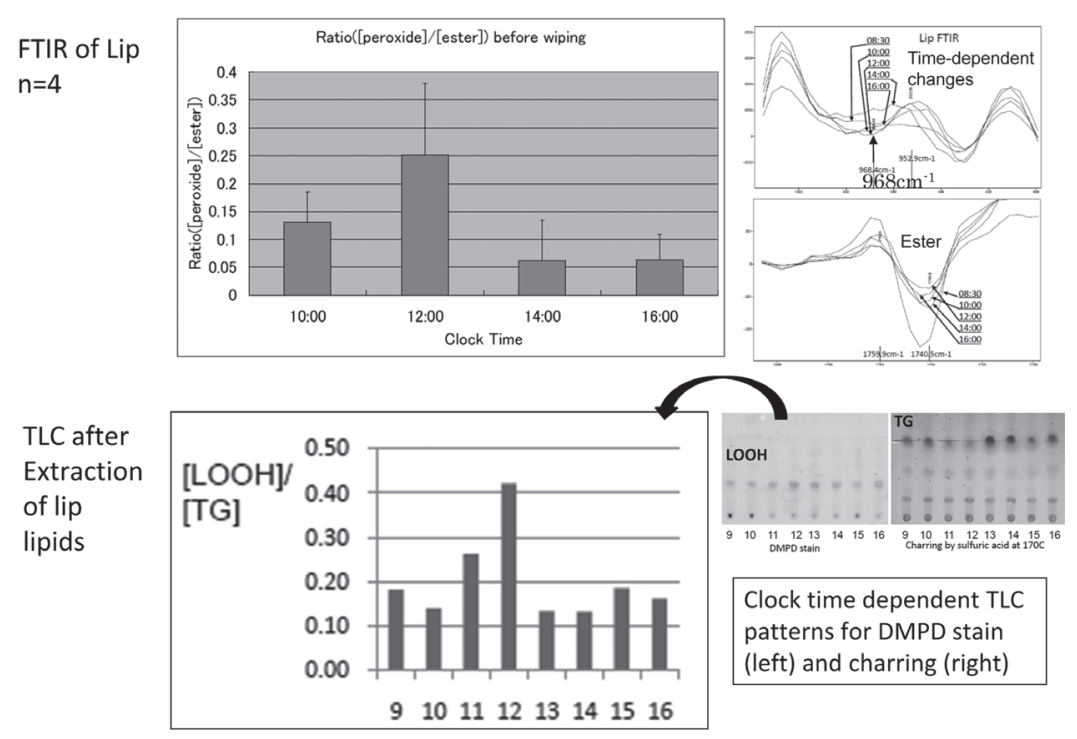

Fig. 1. 口唇表面の過酸化脂質の分析。（上図右）2 次微分赤外スペクトル $\left(968 \mathrm{~cm}^{-1}\right.$ 付近（Peroxidized：上）と $1740 \mathrm{~cm}^{-1}$ 付近 (Ester：下)）の時間変化。(上図左）IR 強度比の時間変化 $\left(\left[968 \mathrm{~cm}^{-1}\right] /\left[1740 \mathrm{~cm}^{-1}\right]\right)$ 。(下図右）口唇表面から抽出し た脂質の TLC パターンの時間変化（DMPD 染色：左，炭化パターン：右，上の濃いスポットがTG）。(下図左） TLC上 の TG および LOOH（DMPD 染色）のスポット濃度比の時間変化。IR の時と同様 12 時（昼食前）に過酸化脂質が相対 的に最大になった。
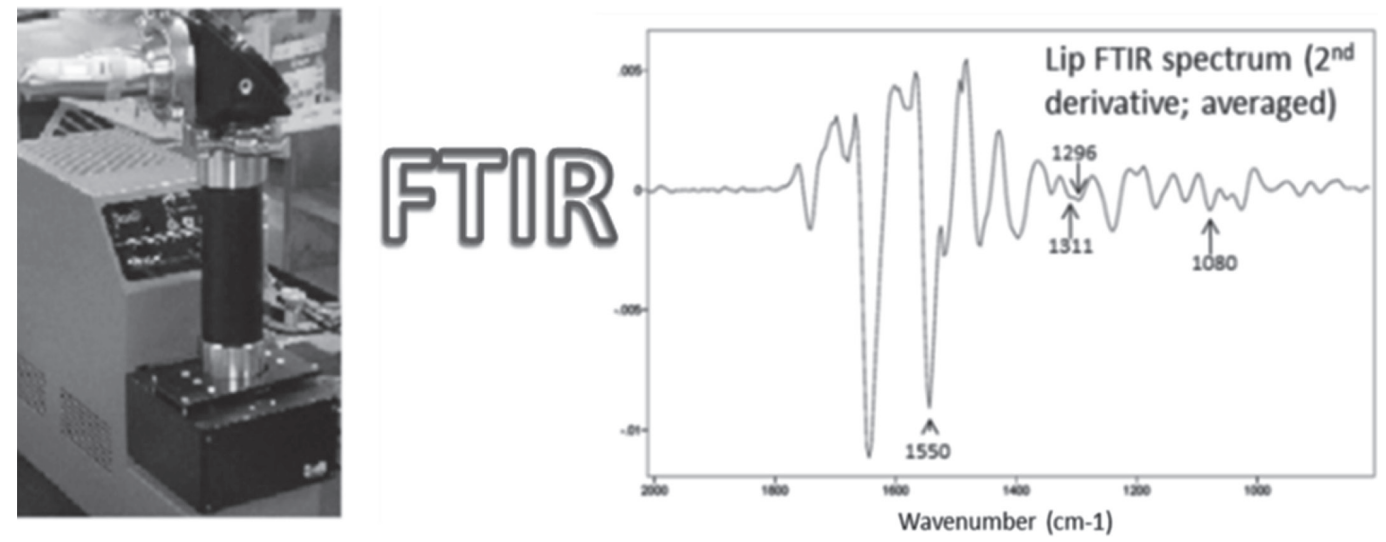

Fig. 2 当研究室で開発した顔面皮膚測定用 FTIR-ATR 装置（左）とそれで測定した口唇表面のIR の 2 次微分スペクトル（被験 者 25 名の平均化スペクトル) (右)。

よって，表面の保湿性が保たれ，またその細胞間ラメラ と角質細胞の物性によってバリア機能が維持される。こ のような特徴を持つ口唇表面を FTIR-ATR 法によって 非侵襲的に簡便に測定できるアダプタを開発し(Fig. 2)， 前記のように脂肪酸の代謝状態を観察することが可能に なった 9111 12)。さらに，この口唇表面の測定によって， 糖尿病のマーカーである $\mathrm{HbAlc}$ 值を予測することを検 討した。糖尿病の非観血的診断（血糖值測定）に振動分 光法を使うというのは古くから試みられてきた方法であ り, 最近では蛍光分光法によって皮膚の AGEs（最終糖 化産物）の測定を行うような装置（Diagnooptics 社； AGE Reader) も開発され試験的に使われているが, ま だ臨床現場で本格的に使用されることは少ない。そこで
FTIR-ATR 法で, 口唇の細胞間ラメラに入ってくるで あろう AGEs を直接測定して, 糖尿病被験者の $\mathrm{HbAlc}$ 值の予測が可能かどうかを, 学内倫理委員会の許可を得 て可搬性の FTIR 装置を病院に持込み，検討した。この 方法で皮膚表面の数十 pmol レベルの AGEs が FTIRATR 法で測定可能であり, 蛍光分光法で検出できない AGEs も計測できた。

その結果, $\mathrm{HbAlc}$ 值が $6.5 \%$ 以上のグループとそれ未 満のグループの口唇の赤外スペクトルを比較し差スペク トルをとると, そのパターンは一部の AGEs（カルボキ シメチル化生成物）の赤外スペクトルとよく相関した。 さらに, PLS 法を適用して各被験者の HbAlc 值を予測 した所，相関係数 $\mathrm{R}=0.82$ と比較的よく予測することが 
できた $(\mathrm{n}=25)$ 。またその予測のときに出てくる偽陰 性の人たちは 2 名（16 名患者中）いたが，口唇のトラ ンス型不飽和脂肪酸由来の $968 \mathrm{~cm}^{-1}$ の赤外吸収強度に よる分類を付け加えることで偽陰性の人たちをすべて見 出し, 高 $\mathrm{HbAlc}$ 值 (6.5\%以上)の被験者を 100\%スクリー

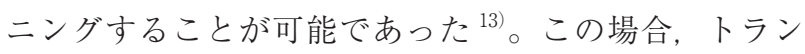
又型不飽和脂肪酸は主として脂質の過酸化物として生成 されたものと考えられるので, AGEsの変化と過酸化物 の変化とを両方考慮することで, 糖尿病のマーカーであ る HbAlc 值をより良く予想できたことを示しているの かもしれない。

\section{NMR 分光法による血中脂質計測法の革新}

血中脂質は主にリポタンパク質の一部として存在する ことが多く,主要脂質であるトリグリセリドやリン脂質, コレステロールなどは LDL や HDL などの形で血液を 介して輸送される。循環器系の病態のマーカーとも考え られているこれらのリポタンパク質の量と質を評価する ことは, 臨床研究にとって重要と考えられており, これ らのリポタンパク質の粒子サイズや数を, NMR 分光法 を用いて非破壊的に測定するサービスを行うリポサイエ ンス社 ${ }^{14)}$ (米国 $\mathrm{NC}$ 州) が知られている。この企業は, Dr. Otvos と Dr. Jeyarajah ${ }^{15)}$ によって 1997 年に創業さ れたが, 現在では世界中のリポタンパク質の疫学的研究 を一手に引き受けている感のある新進の企業となってい る。この NMR 法では, $400 \mathrm{MHz}$ 以上の NMR にフロー・ プローブを取り付け数分で (NMR 測定だけだと約 40 秒; プローブ洗浄と試料注入に約 2 分）血清のメチルプロト ンシグナル形状を計測し，デコンボリューション法に よって VLDL，LDL や HDL の粒子サイズと数のみなら ず，各粒子中のコレステロールや TG 量を予測し LipoProfile として提供するサービスを行なっていた。 メチルプロトンのシグナルは $0.8 \mathrm{ppm}$ 前後に検出される が，サイズが大きく低密度のリポタンパク質（VLDL） の場合，そのシグナルは $0.84 \mathrm{ppm}$ に検出され，またサ イズの小さな高密度のリポタンパク質 (small HDL) で は, $0.78 \mathrm{ppm}$ に検出される。このメチルプロトンのケ ミカルシフトは, リポタンパク質のサイズと非線形であ るが数式に書ける関倸にあることがわかっているので, NMR データからそのサイズを求めることができる。さ らに, 粒子濃度もメチルプロトンの NMR シグナルの形 と面積から求めることができる。各リポタンパク質の 持っているコレステロール (Chol) 量や Chol + TG 量も, 各スペクトルの積分值と比較的良く相関するので，それ らの脂質量も計算することができる。

これらのリポタンパク質の従来の測定法である超遠心
法や電気泳動法などの分離的手法よりも NMR 法のほう が短時間で測定でき, 多数の検体を扱えるので, 特に大 規模な臨床研究において採用され，これまでに200 報近 い論文が出版されているという。最近では新しく Lp (a) やsdLDLなどの測定も手がけて, 臨床研究に貢献して きている。一方でFTIR の方法で血清中の LDL（アポ リポタンパク質）量を測る非破壊的計測方法も提案され ている ${ }^{16)}$ 。

\section{5 まとめ}

人体の脂質脂肪酸の代謝研究あるいは臨床研究におい て, 分光法によって比較的短時間に多数の検体の脂肪酸 組成や脂質量を測定し, 組織中の脂肪酸量を予測できる 様々な手法が開発されその有用性も一部では認識されつ つある。ただ, FTIRによる脂肪酸組成計測や口唇を通 した脂質脂肪酸代謝の計測法はまだ確立されておらず, より有効な手法として認識されるためにはさらなる研究 の広がりと装置技術開発が必要である。そして, 臨床研 究においては脂質脂肪酸代謝の研究と同時に糖代謝や他 の代謝の変化を同じ時間軸で捉えていく必要があり, 様々な代謝が関係する病態の非侵襲的即時的検査法の開 発を人々が希求している限り, 脂質や糖なども一斉に分 析可能な赤外分光法のような分光学的検出法の研究は広 がっていくことが期待される。

\section{文 献}

1) Otto M. Chemometrics: statistics and computer application in analytical chemistry. Wiley-VCH Verlag GmbH, FRG, ISBN 3-527-29628-X (1999).

2) Ripoche A, Guillard S. Meat Science 58 (3), 299-304 (2001).

3) Yoshida S, Yoshida H. Biopolymers, 70 (4), 604-613 (2003).

4) Afseth NK, Segtnan VH, et al. Appl Spectrosc 59 (11), 1324-1332 (2005).

5) Beattie JR, Bell SE, et al. Lipids 41 (3), 287-294 (2006).

6) Yoshida S, Okazaki Y, et al. Lipids 43 (4), 361-372 (2008).

7) http://www.scientificamerican.com/(March 1, 2013: Organic versus Conventional).

8) Brossard N, Croset M, et al. J. Lipid Res. 38, 1571-82 (1997).

9) Yoshida S, Zhang QZ, et al. Lipids in Health and Disease 8: 28 (2009).

10）吉田敏, 酒井久美子, 岡田恵子, 竹下正純. 医学のあ ゆみ, 164 (2), 147-148（1993）。

11) Sakuyama S, Hirabayashi C, et al. Skin Res. Technol. 16 (2), 151-160 (2010).

12) Yoshida S, Koike K. (Book) Chapter 1 in Advances in Planar Lipid Bilayers and Liposomes, (Elsevier; Edit- 
ed by Dr. Aleš Iglič) 13, Pages 1-32, ISBN: 978-0-12387721-5 (2011).

13) Yoshida S, Yoshida M, et al. J. Pharm. Biomed. Anal. 76, 169-176 (2013).

14) http://www.liposcience.com/
15) Otvos JD, Jeyarajah EJ, et al. Clin Chem. 37, 377-386 (1991).

16) Liu KZ, Man A, et al. Anal. Bioanal. Chem. 387, 18091814 (2007) 